\title{
Springtime phytoplankton dynamics in Arctic Krossfjorden and Kongsfjorden (Spitsbergen) as a function of glacier proximity
}

\author{
A. M.-T. Piquet ${ }^{1}$, W. H. van de Poll ${ }^{2}$, R. J. W. Visser ${ }^{1}$, C. Wiencke ${ }^{3}$, H. Bolhuis ${ }^{4}$, and A. G. J. Buma ${ }^{1}$ \\ ${ }^{1}$ Department of Ocean Ecosystems, Energy and Sustainability Research Institute Groningen, University of Groningen, \\ Nijenborgh 7, 9747 AG Groningen, the Netherlands \\ ${ }^{2}$ Department of Biological Oceanography, Royal Netherlands Institute for Sea Research, P.O. Box 59, 1790 AB Den Burg, \\ Texel, the Netherlands \\ ${ }^{3}$ Department of Functional Ecology, Alfred Wegener Institute, Am Handelshafen 12, 27570 Bremerhaven, Germany \\ ${ }^{4}$ Marine Microbiology, Royal Netherlands Institute for Sea Research, P.O.Box 140, 4400 AC Yerseke, the Netherlands
}

Correspondence to: A. M. T. Piquet (a.m.t.piquet@rug.nl)

Received: 22 August 2013 - Published in Biogeosciences Discuss.: 1 October 2013

Revised: 17 February 2014 - Accepted: 27 February 2014 - Published: 23 April 2014

\begin{abstract}
The hydrographic properties of the KongsfjordenKrossfjorden system $\left(79^{\circ} \mathrm{N}\right.$, Spitsbergen) are affected by Atlantic water incursions as well as glacier meltwater runoff. This results in strong physical gradients (temperature, salinity and irradiance) within the fjords. Here, we tested the hypothesis that glaciers affect phytoplankton dynamics as early as the productive spring bloom period. During two campaigns in 2007 (late spring) and 2008 (early spring) we studied hydrographic characteristics and phytoplankton variability along two transects in both fjords, using highperformance liquid chromatography (HPLC)-CHEMTAX pigment fingerprinting, molecular fingerprinting (denaturing gradient gel electrophoresis, or DGGE) and sequencing of $18 \mathrm{~S}$ rRNA genes. The sheltered inner fjord locations remained colder during spring as opposed to the outer locations. Vertical light attenuation coefficients increased from early spring onwards, at all locations, but in particular at the inner locations. In late spring meltwater input caused stratification of surface waters in both fjords. The inner fjord locations were characterized by overall lower phytoplankton biomass. Furthermore HPLC-CHEMTAX data revealed that diatoms and Phaeocystis sp. were replaced by small nano- and picophytoplankton during late spring, coinciding with low nutrient availability. The innermost stations showed higher relative abundances of nano- and picophytoplankton throughout, notably of cyanophytes and cryptophytes. Molecular fingerprinting revealed a high similarity between inner fjord samples from early spring and late spring
\end{abstract}

samples from all locations, while outer samples from early spring clustered separately. We conclude that glacier influence, mediated by early meltwater input, modifies phytoplankton biomass and composition already during the spring bloom period, in favor of low biomass and small cell size communities. This may affect higher trophic levels especially when regional warming further increases the period and volume of meltwater.

\section{Introduction}

The Kongsfjorden $\left(79^{\circ} \mathrm{N}\right.$, West Spitsbergen) is influenced by a highly variable inflow of Atlantic water (AW) from the West Spitsbergen Current (WSC) (Cottier et al., 2005; Hegseth and Tverberg, 2013), which transports relatively warm saline water $\left(T>3{ }^{\circ} \mathrm{C}\right.$ and $\left.S>34.9 \mathrm{psu}\right)$ northwards (Svendsen et al., 2002; Hop et al., 2006; Schlichtholz and Goszczko; 2006). As a result, the fjords located on the western side of Spitsbergen are characterized by relatively mild temperatures, compared with other Arctic locations at similar latitude. Disrupted wintertime cooling of Arctic waters is expected to facilitate the WSC inflow into Kongsfjorden as well as in the Arctic at large. (Buchholz et al., 2010). The Kongsfjorden and adjacent Krossfjorden are glacial fjords that are fed with freshwater by several large glaciers and streams (Svendsen et al., 2002; Cottier et al., 2005). Freshwater influx is highest in summer and co-occurs with a strong 
increase in sediment load, which can strongly limit light penetration (Keck et al., 1999; Svendsen et al., 2002). The meltwater discharge affects a large area in the fjord, up to $45 \mathrm{~km}$ distance from the glacier front and up to $30 \mathrm{~m}$ depth (Keck et al., 1999; Hop et al., 2002; Svendsen et al., 2002; Hop et al., 2006), and leads to strong surface stratification during summer. Due to enhanced WSC influence, the concomitant warming is expected to increase the magnitude and time interval of meltwater influx into Kongsfjorden. The time window of meltwater discharge in Kongsfjorden is not clearly described, in particular to what extent it affects water column characteristics during the spring months (April-June).

The observed hydrographic variability leads to a high level of unpredictability in interannual phytoplankton spring bloom timing, biomass and production. For example, enhanced inflow of warm Atlantic water in Kongsfjorden is associated with changes in phytoplankton abundance and composition (Hodal et al., 2012; Hegseth and Tverberg, 2013): years with less inflow showed diatom dominance during the spring bloom, whereas high inflow years were characterized by Phaeocystis-pouchetii-dominated spring blooms. Therefore, the timing, composition, and biomass of the spring bloom show extensive year-to-year variability (Hegseth and Tverberg, 2013). During summer stratification, diatoms and $P$. pouchetii become nutrient limited, are grazed upon or sink out of the euphotic zone. As a result, a transition occurs towards less-productive, small-sized, but highly diverse plankton communities (Hegseth and Sundfjord, 2008; Piquet et al., 2010). In addition to low nutrient availability, high sediment concentrations derived from glacial melt water input limit light availability for phytoplankton growth during summer. The euphotic zone can be restricted to the upper $0.3 \mathrm{~m}$ close to the glaciers (Keck et al., 1999), leading to highly unfavorable conditions for phytoplankton growth (Hop et al., 2006). Thus, the expected increase in magnitude of land-derived meltwater influx may affect phytoplankton composition and production. In addition, if the onset of meltwater discharge were to start earlier in the spring period (April-June), phytoplankton spring blooms may be affected, in particular at inner fjord locations. In the western Antarctic Peninsula region, changes in phytoplankton composition and size were observed, related with regional warming (Moline et al., 2004; Montes-Hugo et al., 2009). A significant decrease in average phytoplankton cell size was associated with enhanced meltwater input, favoring nanophytoplankton, notably cryptophytes. Similar observations were made in the Pacific Arctic (Canada Basin and Chukchi Sea) where smaller-sized phytoplankton species appeared to thrive under summertime surface freshening and impoverished sea ice conditions ( $\mathrm{Li}$ et al., 2009; Coupel et al., 2012). Summertime freshening was associated with an increase in pico- and bacterioplankton abundance, while altered sea ice conditions caused a spatial shift in phytoplankton distribution as well as an increase in nanoplankton abundance.
Although extensive information exists on larger microalgal species occurring in Kongsfjorden (Hasle and Heimdal, 1998; Keck et al., 1999; Hop et al., 2002), only a few studies described the taxonomic composition in the nano- and picophytoplankton size ranges (Rokkan Iversen and Seuthe, 2011). Molecular techniques offer an efficient, high-resolution approach to complement classical microeukaryotic community analyses. In 2005 we performed a study to investigate summer phytoplankton diversity and composition in Kongsfjorden and Krossfjorden, using a combination of molecular approaches (Piquet et al., 2010). During this study Kongsfjorden and Krossfjorden were found to harbor distinctive micro-eukaryotic communities during the stratified summer period. The results suggested that meltwater input during summer structured marine microbial communities through decreased salinity, increased light attenuation, and strong salinity stratification. However, nothing was known about the possible impact of meltwater discharge during spring and how this would affect timing, extent and composition of phytoplankton dynamics. With increasing global warming, an earlier discharge of fresh meltwater is a likely scenario, and therefore information is required to be able to understand the consequences of enhanced glacial melting on phytoplankton performance, in particular during the season of highest productivity, e.g., April-June.

The aim of the present study was to analyze the dynamics and composition of springtime phytoplankton communities in response to prevailing water mass properties, glacier vicinity and meltwater release. We hypothesize that during the spring bloom period phytoplankton is already affected by glacial meltwater input, in particular at inshore locations. Phytoplankton variability was studied in two consecutive years, covering early spring (2008) and late spring (2007), along a 3-station mini-transects in Kongsfjorden and adjacent Krossfjorden. High-performance liquid chromatography (HPLC)-derived pigment fingerprinting followed by CHEMTAX calculation of taxon-specific contributions to total phytoplankton biomass were related to physical and chemical environmental variables. In addition, molecular characterization of the eukaryotic community provided complementary information on community dynamics, diversity and composition by denaturing gradient gel electrophoresis (DGGE) of partial 18S rRNA genes and direct gene sequencing.

\section{Materials and methods}

\subsection{Field sampling}

Samples were collected in Kongsfjorden $\left(78^{\circ} 57^{\prime} 54^{\prime \prime} \mathrm{N}\right.$, $\left.11^{\circ} 51^{\prime} 24^{\prime \prime} \mathrm{E}\right)$ and Krossfjorden $\left(79^{\circ} 10^{\prime} 00^{\prime \prime} \mathrm{N}, 11^{\circ} 46^{\prime} 00^{\prime \prime} \mathrm{E}\right)$, located on the west coast of Spitsbergen in the Atlantic sector of the Arctic Ocean. The five sampling sites were representative for ocean- to glacier-influenced locations within the fjords. The stations consisted of an "Ocean" station $(\mathrm{O})$ at the 


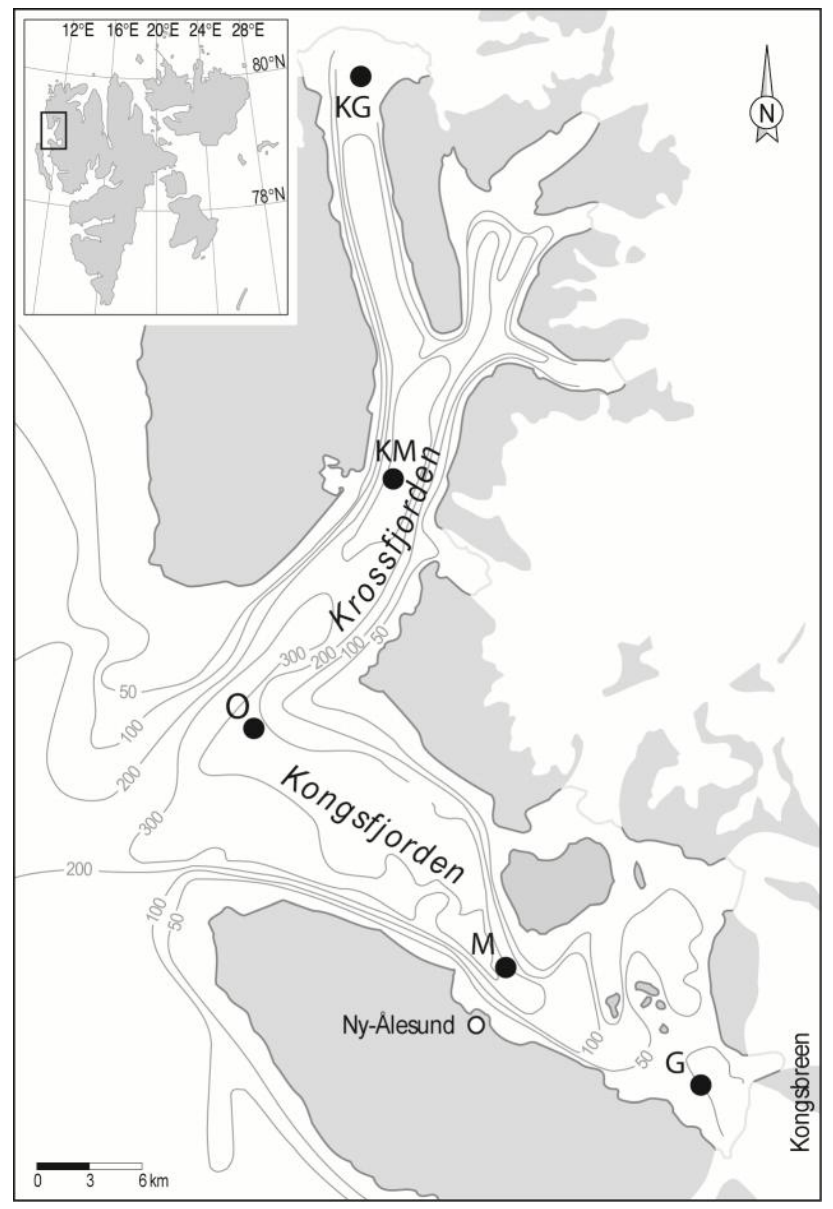

Fig. 1. Bathymetric map of the Kongsfjorden-Krossfjorden system, and inlay map of Svalbard showing the location of the fjords. Sampling locations Ocean (O), Kongsfjorden Middle and Glacier (M and $\mathrm{G}$ ), and Krossfjorden Middle and Glacier stations (KM and $\mathrm{KG}$ ) are shown on the map.

intersection of both fjords, a station in the middle (M, KM) and a station near the main glacier $(\mathrm{G}, \mathrm{KG})$ of each fjord (Fig. 1). Water samples were collected twice a week, provided weather conditions permitted boating activities, during two spring-summer field campaigns in 2007 and 2008. The 2007 campaign was conducted in late spring from 22 May to 25 June 2007, and in early spring of 2008 from 9 April to 12 May.

Standard sampling depths were 0 and $20 \mathrm{~m}$. Surface samples were collected directly using clean $12 \mathrm{~L}$ polyethylene carboys. Deeper samples were collected with a $12 \mathrm{~L}$ Niskin bottle (General Oceanics, Inc.; Miami, Florida, USA) mounted $2 \mathrm{~m}$ above a Sea-Bird CTD (SNE 19plus, Sea-Bird Electronics, Inc.; Bellevue, Washington, USA). The CTD was fitted with a biospherical Li-Cor PAR (photosynthetically active radiation) sensor (Sea-Bird Electronics), and in 2008 supplemented with a Wetstar fluorometer (Wet labs, Inc.; Philomath, Oregon, USA). All samples were collected in the morning, stored cold and dark during transportation and processed within $3 \mathrm{~h}$ at the Kingsbay Marine Laboratory, $\mathrm{Ny}$-Ålesund. Samples for inorganic nutrient analysis were processed immediately on board. For each sample, $5 \mathrm{~mL}$ filtrate was obtained by filtration over a sterile $0.2 \mu \mathrm{m}$ pore size cellulose acetate syringe filter (Whatman GmbH, Dassel, Germany). Vials destined for silica analysis were kept at $4{ }^{\circ} \mathrm{C}$, while vials for nitrate, nitrite, and phosphate analysis were stored at $-80^{\circ} \mathrm{C}$ until analysis on a an AxFlow Bran+Luebbe Traacs 800 autoanalyzer at the Royal NIOZ laboratory (Texel, the Netherlands).

\subsection{Sample processing}

Upon return to the Kingsbay Marine Laboratory water samples were immediately filtered by vacuum pressure (maximum 0.05 MPa). For pigment analysis, $6 \mathrm{~L}$ of seawater were filtered onto $47 \mathrm{~mm} \mathrm{GF} / \mathrm{F}$ filters. The filters were snap-frozen in liquid nitrogen and stored at $-80^{\circ} \mathrm{C}$ until analysis. For molecular analysis, we filtered 1.5 to $2 \mathrm{~L}$ of seawater onto $47 \mathrm{~mm} 2 \mu \mathrm{m}$ pore size polycarbonate filters (Merck Millipore; Massachusetts, USA). The use of $0.2 \mu \mathrm{m}$ polycarbonate filters, which might have been more appropriate to cover the full phytoplankton size spectrum, was not successful. This pore size caused early clogging of filters due to the presence of inorganic particles, and as a result restricted the filter volume but elongated filtration time beyond what was acceptable. Therefore we chose to use $2 \mu \mathrm{m}$ filters, even though we were aware of (partly) losing $<2 \mu \mathrm{m}$ picophytoplankton cells. Filters were stored at $-80^{\circ} \mathrm{C}$, until further analysis in the home laboratory. For qualitative microscopy analysis, $1 \mathrm{~L}$ of seawater was fixed with Lugol's iodine solution (1\% final concentration) supplemented with formaldehyde ( $2 \%$ final concentration) and left to settle at $4{ }^{\circ} \mathrm{C}$. After one week, samples were concentrated to $100-150 \mathrm{~mL}$ by careful siphoning of the supernatant. The concentrated samples were transferred to $150 \mathrm{~mL}$ brown glass bottles with a Teflon-lined screw cap and kept in the dark at $4{ }^{\circ} \mathrm{C}$ until processing.

\subsection{Pigment analysis}

Filters were freeze-dried for $48 \mathrm{~h}$ and immediately extracted in $5 \mathrm{~mL} 90 \%$ acetone $\left(v / v, 48 \mathrm{~h}, 4^{\circ} \mathrm{C}\right)$ in the dark. Pigments were quantified using HPLC. Pigment extracts were separated on a Waters 960 HPLC system using a $\mathrm{C}_{18} 5 \mu \mathrm{m}$ DeltaPak reversed phase column (Waters) as described in van Leeuwe et al. (2006). The different pigments were identified by retention time and diode array detection at $436 \mathrm{~nm}$. The HPLC was calibrated using pigment standards obtained from DHI LAB Products (Denmark), which included all pigments used in the CHEMTAX analysis. The CHEMTAX 1.95 program (Mackey et al., 1996) was used to determine the taxonomic contribution of different phytoplankton groups. The program uses the steepest-descent algorithm to determine the best fit based on an estimate of 
pigment:Chl $a$ ratios for different algal classes (Mackey et al., 1996). We used an initial pigment-ratio matrix derived from a Southern Ocean data set to compute our data. The pigments implemented in the CHEMTAX analysis were Chl c 3,19'-butanoyloxyfucoxanthin, fucoxanthin, 19'hexanoyloxyfucoxanthin, prasinoxanthin, peridinin, alloxanthin, violaxanthin, lutein, zeaxanthin, $\mathrm{Chl} a$ and $\mathrm{Chl} b$. The analysis provides estimates on the relative contribution of dinoflagellates, cryptophytes, chlorophytes (chlorophytes and prasinophytes were not distinguished), diatoms, haptophytes (where haptophytes 6 and 8 were pooled) and cyanophytes. From the CHEMTAX results the pico-nanophytoplankton fraction was calculated, which was for this study based on cyanophytes+cryptophytes+chlorophytes only. We omitted the dinoflagellates and haptophytes in these calculations, because dinoflagellate diversity was high, consisting of athecate and thecate cells in both $\ll 20 \mu \mathrm{m}$ and $\gg 20 \mu \mathrm{m}$ size ranges (as revealed by microscopy). In addition, the colony form of Phaeocystis sp. ( $\gg 20 \mu \mathrm{m})$ seemed to dominate the haptophyte community (based on microscopic inspection).

\subsection{Microscopy analysis}

A few samples (30) were selected for microscopy analysis, mainly for comparative purposes associated with the CHEMTAX and molecular fingerprinting outcomes. Microscopy samples were processed following the Untermöhl technique. Ten to $25 \mathrm{~mL}$ of fixed samples was left to settle for $48 \mathrm{~h}$ in counting chambers. Phytoplankton species composition was qualitatively assessed, along one or two meridians at $40 \times$ and $200 \times$ magnifications on an Olympus IMT- 2 inverted microscope.

\subsection{DNA extraction and amplification}

For molecular fingerprinting and sequencing, genomic DNA was extracted under sterile conditions as described previously (Piquet et al., 2010). DNA amplification of the 18S rRNA gene was carried out with the universal eukaryotic primer set Euk1A and Euk516r (Díez et al., 2001). We also used Euk1 A in combination with the GC-clamp enriched reverse primer (Euk516r-GC) for denaturing gradient gel electrophoresis (DGGE). Approximately $10 \mathrm{ng}$ of DNA was used as a template in the polymerase chain reaction (PCR); $50 \mu \mathrm{L}$ PCR contained each primer at a concentration of $300 \mathrm{nM}$, as well as $0.2 \mathrm{mM}$ dNTPs, $2 \mathrm{mM} \mathrm{MgCl}_{2}, 1 \%$ deionized formamide, $1 \times$ PCR buffer, and $2.5 \mathrm{U}$ Taq DNA polymerase (Eurogentec, Belgium). Amplification reactions were run on a thermal cycler (VWR Unicyler, Gene Technologies Ltd, UK, and Peltier Thermal Cycler, MJ Research INC, USA) using the cycling conditions as described previously (Díez et al., 2001). Amplicon fragment size and yield was determined by comparison with DNA smart ladder (Eurogentec, Belgium) on a $1 \%$ agarose gel.

\subsection{Denaturing gradient gel electrophoresis}

DGGE analysis of the PCR products was carried out on a PhorU system (Ingeny, Goes, NL). Optimal fragment separation was obtained with a $15-55 \%$ formamide-urea gradient $(100 \%$ denaturants defined as $7 \mathrm{M}$ urea and $40 \%$ formamide (Muyzer et al., 1993). For all samples we loaded $80 \mathrm{ng}$ of PCR product with $1 \%$ final concentration loading buffer $(0.05 \%$ w/v bromophenol blue, $40 \%$ w/v sucrose, $0.1 \mathrm{M}$ EDTA pH 8.0, $0.5 \%$ sodium lauryl sulfate). For each sampling location, all samples were run on a single full DGGE (maximum of 40 samples on a 48-wells gel). An additional gel was run with samples from different locations, selected according to the temporal extremes of our data set, corresponding to early, mid- and late spring. The polyacrylamide gels were silver-stained (Heuer et al., 2001), dried $\left(4 \mathrm{~h}, 60^{\circ} \mathrm{C}\right)$, and scanned using a high-resolution Epson Perfection V700 photo scanner (Epson, USA). DGGE fingerprints were analyzed using the Bio-Numerics ${ }^{\circledR}$ version 3.5 (Applied Maths). DGGE band patterns were digitalized and normalized using flanking marker samples. All positive bands (minimum $4 \%$ profiling and $0.5 \%$ surface area) were assigned to band classes, and the relative abundance was set to band surface (area under the Gaussian curve representing the band). The Pearson correlation coefficient $(r)$ for each pair of lanes within a gel was calculated as a measure of similarity between the community profiles, and the cluster analysis was performed by applying the unweighted pair group method with mathematical averages (UPGMA). Furthermore relative abundance data were used for diversity and multivariate analyses.

\subsection{Sanger sequencing}

We selected samples from our data set that represented early, mid-, and late spring samples from Ocean (O), Kongsfjorden and Krossfjorden Glacier stations (G, KG). In total 10 surface samples were selected (9 April 2008 Ocean; 14 April 2008 Glacier; 16 April 2008 Krossfjorden Glacier; 6 May 2008 Krossfjorden Glacier; 12 May 2008 Ocean \& Kongsfjorden Glacier; 21 June 2007 Ocean \& Krossfjorden Glacier; 25 June 2007 Kongsfjorden Glacier) for generating clone libraries. All samples were amplified with the Euk1A-Euk516R primer set as described above but using the GoTaq ${ }^{\circledR H o t S t a r t ~ P o l y m e r a s e ~(P r o m e g a ; ~ L e i d e n, ~ t h e ~}$ Netherlands). PCR products (520 bp fragments) were ligated into pGEM-t vector (Promega) and transformed into E. coli $\mathrm{DH} 5 \alpha$ competent cells (Sylphium Life Sciences ${ }^{\mathrm{TM}}$, Groningen, the Netherlands). For each sample, 150-170 white colonies were selected and amplified from the vector's T7-SP6 sites. In total $30 \mathrm{ng}$ of PCR product was cleaned using ExoSAP-IT (Affymetrix; Cleveland, USA) and used as a template in the sequencing reaction performed with BigDye ${ }^{\circledR}$ 3.1 Terminator buffers (Applied Biosystems) and $0.2 \mathrm{mM}$ 
T7 primer. Sequences were run on an Applied Biosystems $3730 \times 1$ Genetic Analyzer.

\subsection{Sequence analysis}

All sequences were manually checked and trimmed using Chromas software version 2.3 (Technelysium, Australia), and closest identity to other sequences was checked using NCBI (National Center for Biotechnology Information) BLAST (Basic Local Alignment Search Tool). All suspected chimeric sequences were fragmented into smaller portions and run in BLAST. Chimeric sequences and fragments $<500$ bp were excluded from the data set. Molecular Evolutionary Genetics Analysis (MEGA) version 4.0 (Tamura et al., 2007) and its add-in ClustalW was used to align the DNA sequences and to calculate pairwise DNA distance matrix using the Kimura 2-parameter model (Hartl et al., 1994; Zhu and Bustamante, 2005). All sequences were attributed to operational taxonomic units (OTUs) defined at the $97 \%$ similarity level using mothur software (Schloss et al., 2009). All sequences were submitted to the NCBI database (accession number KF534518-KF534631).

\subsection{Meteorological data}

Wind speed and direction, air temperature and irradiance were obtained from the AWIPEV observatory.

\subsection{Data processing and statistical analysis}

The attenuation coefficient for PAR $\left(K_{d}\right)$ was calculated from linear regression on $\ln$ transformed irradiance data versus depth, and the $1 \%$ depth for PAR was calculated. Diversity data were calculated using PAST software version 2.16 (Hammer et al., 2001). Statistical testing was run using Statistica 8.0. Student's $t$ tests and linear regressions (Kd, nutrient removal) were performed in Excel.

\section{Results}

\subsection{Environmental conditions}

Slight yet significant sea surface salinity (SSS) differences were found in April-May (2008) within Kongsfjorden. Station $\mathrm{G}$ surface waters showed a significantly lower surface salinity ( $t$ test, $p<0.005$ ) with an average of $34.76 \mathrm{psu}$ ( \pm 0.10 ), compared to $\mathrm{O}$ and $\mathrm{M}$ stations that had average surface salinities of $34.93 \mathrm{psu}( \pm 0.05)$ and $34.92 \mathrm{psu}( \pm 0.05)$, respectively. Station KG occasionally showed strongly reduced surface salinities, most likely caused by melting of observed sea ice drifting within the inner Krossfjorden. The late spring season of 2007 (May-June) showed significant meltwater effects: by mid-June surface water salinities had decreased considerably. The lowest SSS 31.79 psu, was recorded on 25 June near the Kongsfjorden Glacier.

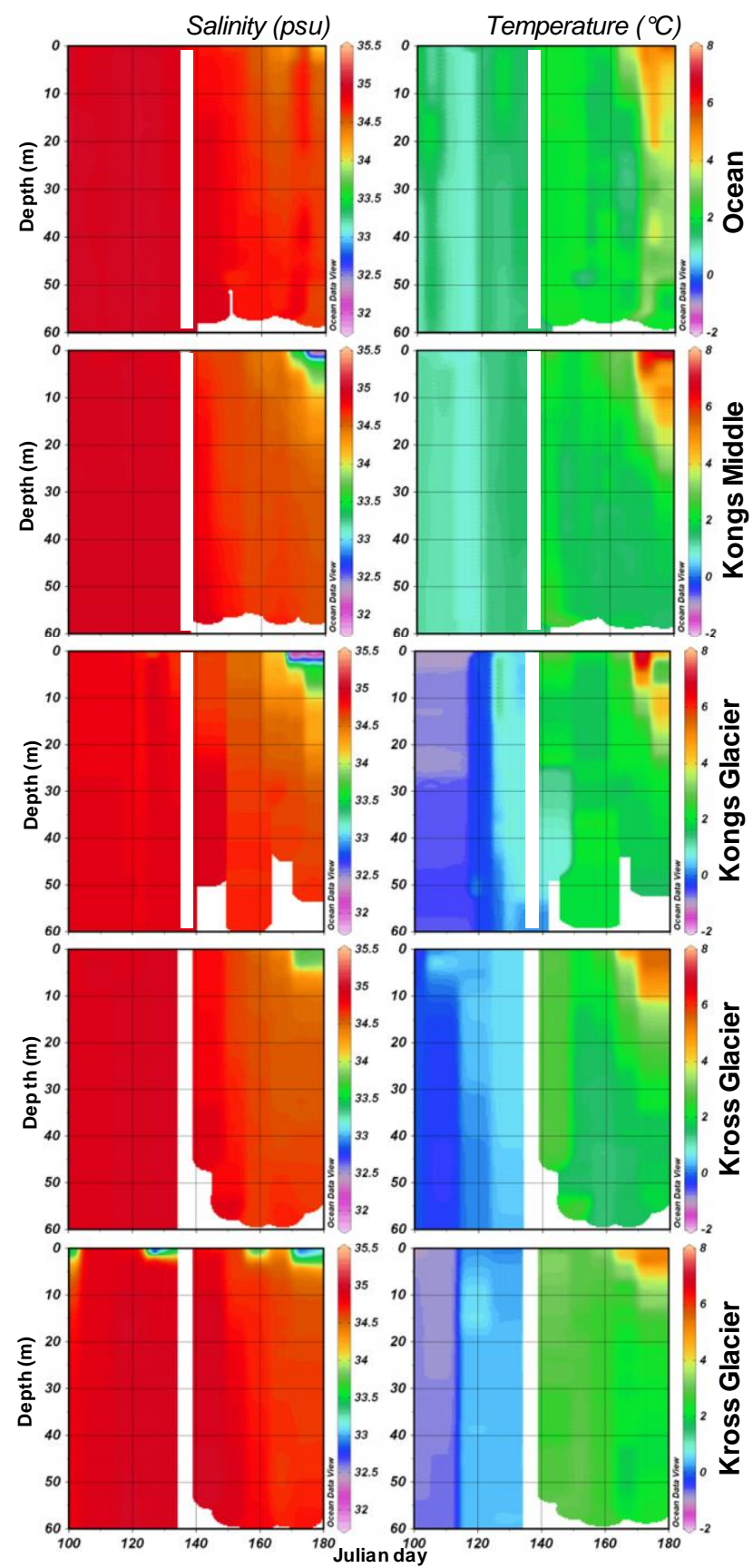

Fig. 2. Water salinity and temperature profiles of the upper $60 \mathrm{~m}$, and of the five sampling stations collected over time in Julian days (JD 100 is 9 April; JD 177 is 25 June). The 2008 (left panel) and 2007 (right panel) sampling periods are separated by a white section.

The freshwater inflow led to significantly lower SSS at all inner locations between 14 and 25 June at the G, M and KG stations (33.41 psu $( \pm 1.04)$ vs. 34.53 psu $( \pm 0.3), t$ test $p<0.01$ ). Decreased surface salinities generally coincided with increased sea surface temperatures (Fig. 2) at all locations. 


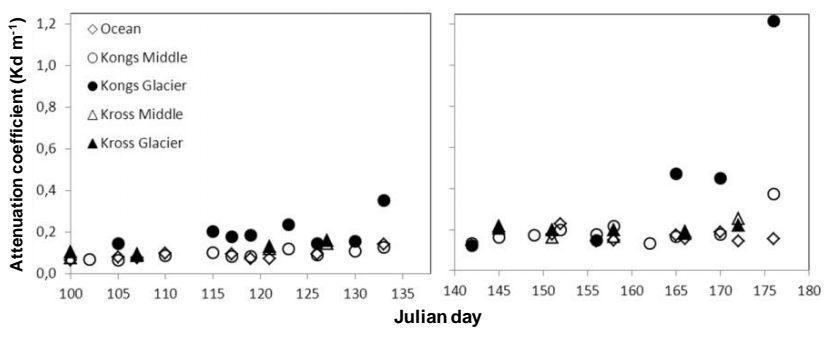

Fig. 3. Change in light attenuation coefficients over time (Julian days) for the 5 stations. Kongs $=$ Kongsfjorden; Kross $=$ Krossfjorden. Left panel: 2008 campaign; right panel: 2007 campaign.

On average, sea surface temperatures were significantly lower in 2008 (average $\mu=0.63{ }^{\circ} \mathrm{C} \pm 0.79$ ) than in 2007 ( $\mu=2.92{ }^{\circ} \mathrm{C} \pm 1.07 ; t$ test, $n=68, t=12163, p<0.001$ ) (Fig. 2). In spring 2008 (April-May) clear differences in water temperatures were observed between sampling stations. Ocean and Kongsfjorden Middle (stations $\mathrm{O}$ and M) stations had significantly higher temperatures than the Krossfjorden (stations $\mathrm{KM}$ and $\mathrm{KG}$ ) and Kongsfjorden inner Glacier (station $\mathrm{G}$ ) station $\left(\mu T_{\mathrm{O} \cap \mathrm{M}}=1.23^{\circ} \mathrm{C} \pm 0.35\right.$; $\mu T_{\mathrm{Kr} \cap \mathrm{G}}=-0.04{ }^{\circ} \mathrm{C} \pm 0.58 ; t$ test $\left.p<0.0001\right)$.

\subsection{Light attenuation}

For all stations, vertical light attenuation $\left(K_{d}\right)$ gradually increased over time, meaning that over time less light penetrated within the water column and led to a shallower euphotic layer (Fig. 3). Both glacier stations (G, KG) showed enhanced $K_{d}$ values already from the beginning of the season (April 2008 campaign), in particular near the Kongsfjorden Glacier. The $K_{d}$ coefficients for this station were significantly different from $K_{d}$ 's observed at the other stations (one-way ANOVA, $p<0.01$ ). Here, $K_{d}$ increased from $0.15 \mathrm{~m}^{-1}$ in early April to $1.22 \mathrm{~m}^{-1}$ at the end of spring in 2007. As a result $1 \%$ light depths, which define the euphotic layer boundary, decreased from $32 \mathrm{~m}$ in early April to $3.7 \mathrm{~m}$ at the end of the 2007 campaign (25 June) near the Kongsfjorden Glacier. Station KG also showed elevated $K_{d}$ values as compared with the outer stations, ranging between $0.10 \mathrm{~m}^{-1}$ (early April) and $0.22 \mathrm{~m}^{-1}$ (21 June) (Fig. 3), leading to $1 \%$ light depths decreasing from approximately 40 to $25 \mathrm{~m}$ during the course of the season. The middle fjord stations $(\mathrm{M}$ and $\mathrm{KM})$ and station $\mathrm{O}$ had lowest $K_{d}$ values at the start of the season in 2008 ( $K_{d}$ values of $0.063,0.070$, $0.077 \mathrm{~m}^{-1}$ for $\mathrm{O}, \mathrm{M}$, and $\mathrm{KM}$, respectively), giving rise to $1 \%$ light depths $>70 \mathrm{~m}$. However, also at these stations $K_{d}$ 's increased right from the beginning of the season, up until $1 \%$ light depths of 30,12 and $18 \mathrm{~m}$, for $\mathrm{O}, \mathrm{M}$ and $\mathrm{KM}$, respectively, at the end of the season.
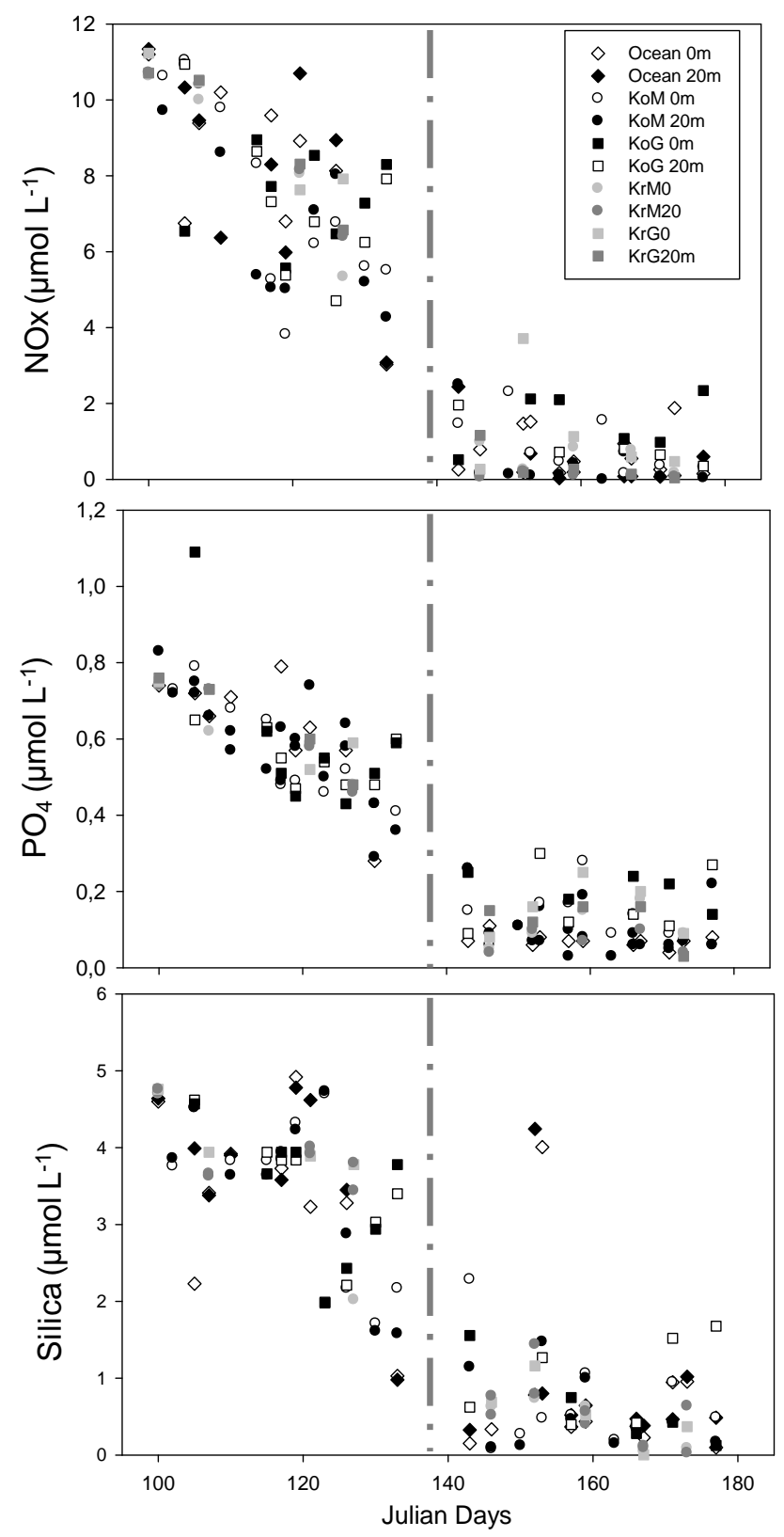

Fig. 4. Nitrate, phosphate and silica concentrations from the five sampling locations collected over time in Julian days. The dotted line separates the 2008 (left panel) from the 2007 (right panel) sampling period.

\subsection{Nutrients}

During the early spring campaign of 2008 nutrients generally showed a decreasing trend, while during late spring (2007) nutrient concentrations remained stable but at low levels (Fig. 4). The 2007 nutrient concentrations were significantly lower than in 2008 for all nutrients $(t$ test, $p<$ 0.001). Maximum starting values at the beginning of the season were $11.3 \mu \mathrm{M}$ for $\mathrm{NO}_{\mathrm{x}}\left(\mathrm{NO}_{3}^{2-}+\mathrm{NO}_{2}^{-}\right), 0.83 \mu \mathrm{M}$ for 

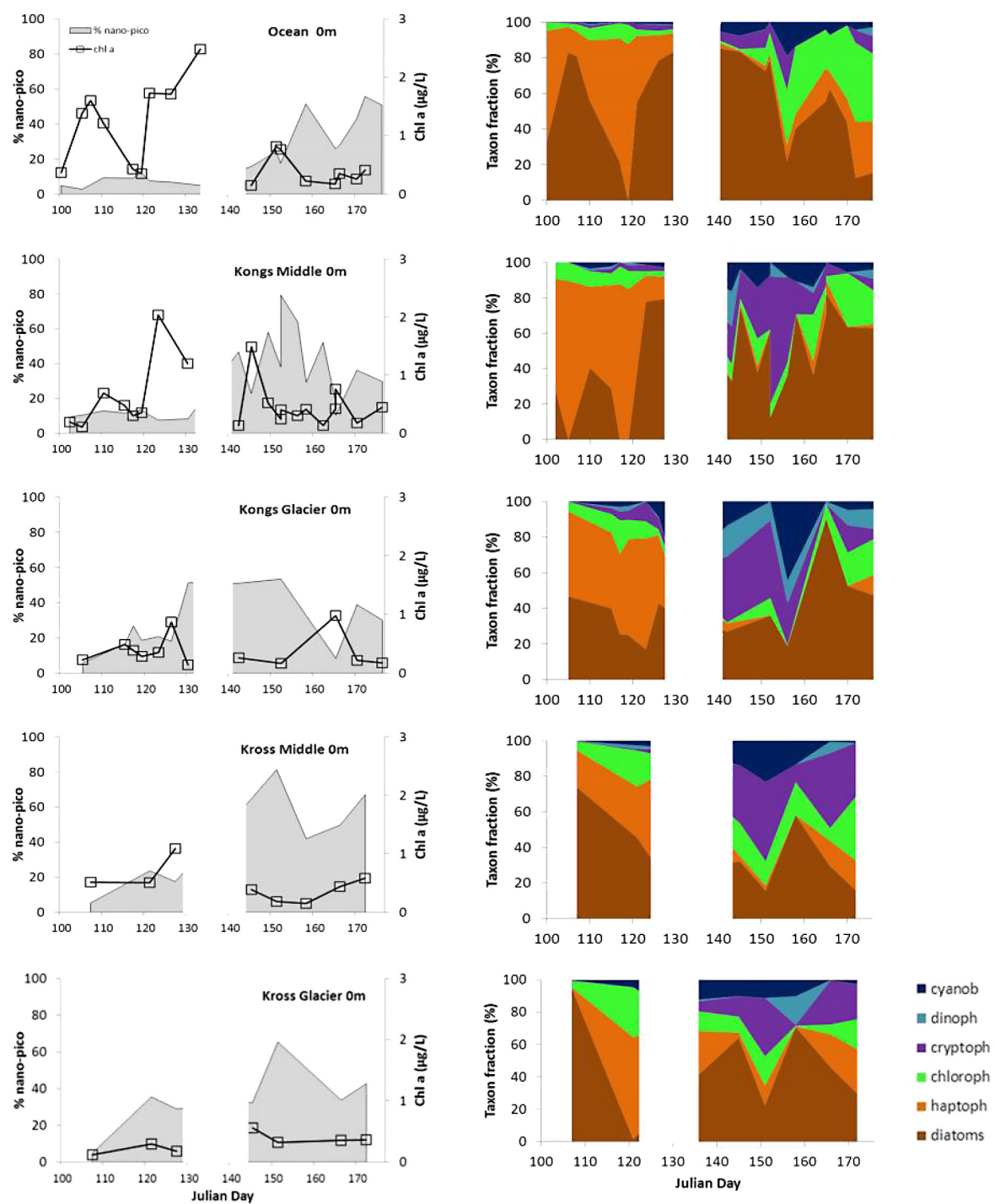

Fig. 5. Surface samples pigment data of all stations over time (Julian days). Left panel shows surface biomass (black line) and the relative contribution of nano-picoplankton to the total Chl $a$ (grey surface). Right panel shows the relative pigment class composition (cyanophytes, dinoflagellates, cryptophytes, chlorophytes, haptophytes and diatoms) to the total Chl $a$.

$\mathrm{PO}_{4}$, and $4.8 \mu \mathrm{M}$ for Si. Although a decreasing trend was observed at all stations, differences between stations were found. The strongest decrease in $\mathrm{NO}_{\mathrm{x}}$ was observed at both middle stations, $\mathrm{M}$ and $\mathrm{KM}$. The rate of nutrient decrease over time was calculated and given as removal rates (Table 1). In 2008, the highest $\mathrm{NO}_{\mathrm{x}}$ removal rates were 0.177 and $0.171 \mu \mathrm{moll}^{-1} \mathrm{~d}^{-1}$ for $\mathrm{M}$ and $\mathrm{KM}$, respectively $(0$ and $20 \mathrm{~m}$ samples pooled). The other stations showed lower or no $\mathrm{NO}_{\mathrm{x}}$ removal. At the Kongsfjorden Glacier station no removal trend was found $\left(R^{2}=0.01\right.$, Table 1$)$, while samples from station KG showed a better fit $\left(R^{2}=0.92\right)$ and much lower $\mathrm{NO}_{\mathrm{x}}$ removal rates as compared with the Middle and Ocean station. $\mathrm{PO}_{4}^{3-}$ removal was similar for all stations, ranging between 0.009 and $0.011 \mu \mathrm{mol} \mathrm{L}^{-1} \mathrm{~d}^{-1}$ (Table 1). In contrast, silicate removal varied greatly between stations, with the KG station showing the lowest $\left(0.027 \mu \mathrm{mol} \mathrm{L}^{-1} \mathrm{~d}^{-1}\right)$ and station $\mathrm{M}$ the highest $\left(0.072 \mu \mathrm{mol} \mathrm{L}^{-1} \mathrm{~d}^{-1}\right)$ removal rate (Table 1$)$.

\subsection{Phytoplankton biomass}

Chlorophyll $a$ concentration $\left(\mu \mathrm{g} \mathrm{L}{ }^{-1}\right)$ showed high variability in space and time. Chl a levels were relatively high in early spring (2008 campaign) at the Ocean and Middle Kongsfjorden stations (Fig. 5 left panels). Nevertheless, in surface waters, Chl $a$ never exceeded $2.5 \mu \mathrm{g} \mathrm{L}^{-1}$. A phytoplankton bloom seemed to develop during early spring at the Ocean and Middle Kongsfjorden stations; however, surface Chl $a$ concentrations dropped sharply in the third week of April (2008) (Fig. 5). On average, Chl $a$ 
Table 1. Early spring nutrient removal rates.

\begin{tabular}{lccc}
\hline Station & $\mathrm{NO}_{\mathrm{x}}$ & $\mathrm{PO}_{4}^{3-}$ & $\mathrm{SiO}_{3}^{2-}$ \\
\hline Ocean $(\mathrm{O})(n=18)$ & $-0.158(0.44)$ & $-0.011(0.57)$ & $-0.057(0.27)$ \\
Kongs Middle $(\mathrm{M})(n=20)$ & $-0.177(0.58)$ & $-0.011(0.80)$ & $-0.072(0.46)$ \\
Kongs Glacier $(\mathrm{G})(n=16)$ & $-0.057(0.01)$ & $-0.010(0.33)$ & $-0.060(0.37)$ \\
Kross Middle $(\mathrm{KM})(n=8)$ & $-0.171(0.91)$ & $-0.009(0.89)$ & $-0.052(0.50)$ \\
Kross Glacier $(\mathrm{KG})(n=8)$ & $-0.147(0.92)$ & $-0.009(0.87)$ & $-0.027(0.51)$ \\
\hline $\mathrm{NO}_{\mathrm{x}}, \mathrm{PO}_{4}^{3-}$ and $\mathrm{SiO}_{3}^{2-}$ removal $\left(\mu \mathrm{mol} \mathrm{L}^{-1} \mathrm{~d}^{-1}\right)$ over time for the 5 stations, based on linear regression \\
analysis of dissolved nutrients for 0 and $20 \mathrm{~m}$ samples (pooled) of 2008 samples. $\left(R^{2}\right.$ : regression \\
coefficient).
\end{tabular}

concentrations were lower at stations G, KG and KM. For comparison, average $\mathrm{Chl} a$ concentrations during the 2008 campaign were $1.25( \pm 0,74) \mu \mathrm{g} \mathrm{L}^{-1}$ for the Ocean station, and $0.35( \pm 0.26) \mu \mathrm{g} \mathrm{L}^{-1}$ and $0.19( \pm 0.09) \mu \mathrm{g} \mathrm{L}^{-1}$ for $\mathrm{G}$ and $\mathrm{KG}$, respectively. During the late spring campaign of 2007 , Chl $a$ levels were low everywhere, ranging between 0.37 $( \pm 0.25) \mu \mathrm{g} \mathrm{L}^{-1}$ at station $\mathrm{O}$ and $0.31( \pm 0.33) \mu \mathrm{g} \mathrm{L}^{-1} \mathrm{Chl} a$ at station G. No significant differences between 0 and $20 \mathrm{~m}$ Chl $a$ levels were found (results not shown).

\subsection{Phytoplankton pigment fingerprints - CHEMTAX}

The taxonomic composition of the phytoplankton as revealed by taxon-specific pigment markers showed a high variability in space and time (Fig. 5, right panels). Similar to the Chl $a$ data, no significant differences were found between 0 and $20 \mathrm{~m}$ samples from the same location; therefore only surface patterns are shown (Fig. 5). In four samples from the Krossfjorden stations, 2008 campaign, pigment levels were too low ( $\left.\ll 0.1 \mu \mathrm{g} \mathrm{Chl} a \mathrm{~L}^{-1}\right)$ to detect the essential pigments required for a reliable CHEMTAX calculation. Pigment fingerprints showed that diatoms and haptophytes dominated in early spring (2008 campaign). These groups were replaced by other taxonomic groups during the late spring campaign (2007). Here (nano-)flagellates dominated as well as cyanophytes, giving rise to a significantly enhanced fraction in the nano-pico size ranges (Fig. 5, left panels) (one-way ANOVA, $p<0.0001)$. Moreover, differences were found on the spatial scale. The highest relative abundance of diatoms and haptophytes was measured in the Ocean and Kongsfjorden Middle samples during early spring (2008) with the Ocean station showing the highest average diatom abundance during both campaigns (51 and 53\% in 2008 and 2007, respectively). Remarkably, in 2008, the microphytoplankton composition at the glacier locations from both fjords and the Krossfjorden Middle station differed significantly from the Ocean and Kongsfjorden Middle stations, with lower relative amounts of diatoms and haptophytes (Tukey test, $p<0.001$; $p<0.005)$, but enhanced fractions of chlorophytes, cryptophytes and cyanophytes leading to an enhanced contribution of the nano-pico fractions (Fig. 5, left panels). Overall, at the end of the 2008 campaign (12 May) both outer sta- tions $(\mathrm{O}, \mathrm{M})$ showed nano-pico fractions well below $10 \%$, while at the Kongs Glacier station in particular values above $30 \%$ were found. At the start of the late spring campaign of 2007 this trend was also visible: the relative dominance of diatoms at the Ocean station decreased towards the inner parts of the fjords. At these inner locations, cryptophytes as well as cyanophytes were highly abundant. At the end of this campaign the nano-pico fraction at the Ocean station had increased, which was mainly due to enhanced chlorophyte abundance, whereas cryptophyte abundance remained relatively low. Based on CHEMTAX, dinoflagellate abundance was never high, but a general increase in relative abundance was found during the late spring campaign, as compared with early spring. Qualitative microscopic analysis confirmed the CHEMTAX outcomes in particular with respect to cryptophyte presence at the glacier locations. Here small-sized phytoplankton (cryptophytes, small dinoflagellates, occasional pennate diatoms) were often accompanied by small ciliates showing an average cell length of approximately $15 \mu \mathrm{m}$. At the end of the late spring campaign (19 and 21 June 2007, Julian day (JD) 170 and 172) both glacier stations showed high numbers of cryptophytes in various sizes $<20 \mu \mathrm{m}$, whereas Ocean samples had numerous fragments of Phaeocystis colonies. During early spring (9 and 16 April 2008) the diatom community at this location consisted mainly of Thalassiosira spp., pennate chain forming diatoms, and Chaetoceros species in lower numbers. During late spring tintinnids and other ciliates of various sizes $(<20 \mu \mathrm{m},>20 \mu \mathrm{m})$ were highly abundant at all locations.

\subsection{Eukaryotic community - molecular fingerprints}

DGGE was applied to all samples, keeping samples from one location on separate gels. Similarity analysis of band patterns from a given sampling station generally showed clustering according to time and depth (data not shown). Ordination analysis and individual environmental variable testing confirmed that factors time, temperature, nutrients and depth significantly explained part of the variation observed for communities from a given sampling location.

Pearson's similarity analysis of the band patterns of the additional gel containing samples from different locations 


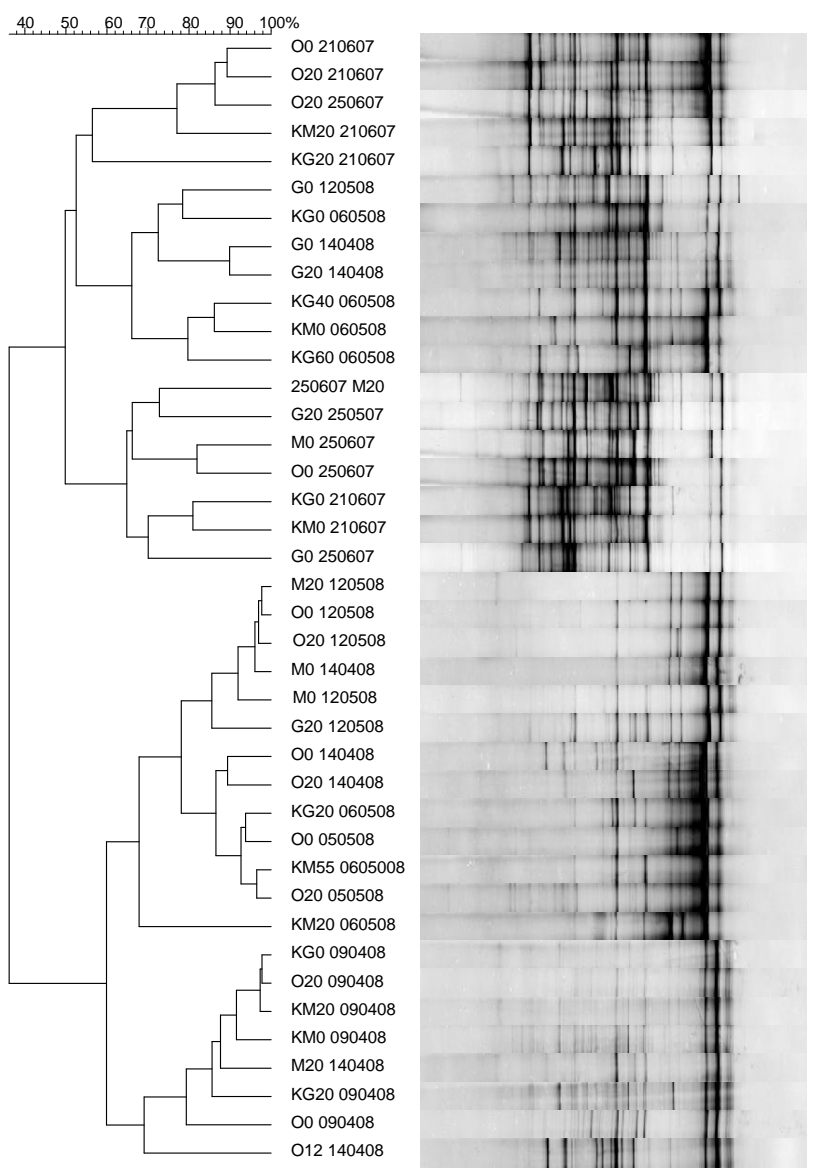

Fig. 6. Dendrogram of DGGE profiles of PCR-amplified 18S rRNA gene fragments from temporal selection of the five sampling locations. The samples were selected according to the maximal temporal range covered by the two field campaigns (early April, early May and end of June). Cluster analysis was based on Pearson's correlation index and the unweighted pair-group method with arithmetic averages.

and sampling days revealed two main clusters as shown in Fig. 6. The first cluster included samples with high band pattern diversity, and the second cluster sampling with lower band numbers. The high-diversity cluster consisted of late spring (2007) samples collected at the onset of glacier melt water influence. Several 2008 samples were included within the " 2007 cluster". Those 2008 samples were collected at stations G, KM and KG. Noticeably, within the "2007" cluster all fjord surface samples formed a distinct cluster from $20 \mathrm{~m}$ samples, indicative of stratification. This surface water cluster appeared to share strong similarity with $20 \mathrm{~m}$ samples collected on 25 June at the Kongsfjorden Glacier and Middle station. Overall, samples collected during early-mid-spring from inner fjord stations appeared to share more similarity with glacier-influenced late spring samples.

The cluster exhibiting lower diversity included exclusively 2008 samples. Furthermore there was a temporal and spa- tial separation between early spring and mid-spring samples, representing a pre-bloom and a bloom community, respectively. The early spring (pre-bloom) samples included relatively more Krossfjorden samples, whereas the mid-spring cluster consisted mostly of $\mathrm{O}$ and $\mathrm{M}$ station samples. The clustering suggests that the pre-bloom community was sustained longer in Krossfjorden.

\subsection{Molecular community composition - clone library sequencing}

For each clone library we sequenced between 134 and 154 clones, yielding a total of 1457 sequences of a $+/-520$ bp section of the $18 \mathrm{~S}$ rRNA gene (position 1 to 520). From the 1457 sequences we identified 65 OTUs at the 0.03 cut-off level and 49 singletons. In Table 2 we list the environmental clone and the isolate sharing most identity with each OTU and the relative sequence distribution of each OTU for each sample. Overall we identified 760 Alveolata (Dinophyceae, Syndiniales and Ciliophora)-, 107 Haptophyceae (Prymnesiales)-, 66 Viridiplantae (Chlorophyta)-, 83 stramenopiles (Bacillariophyta, Pelagophyceae, Chrysophyceae)-, 18 Cryptophyta (Pyrenomonadales)-, 12 Picozoas (formerly known as picobiliphytes; Not et al., 2007; Seenivasan et al., 2013)-, 78 Rhizaria (Cercozoa, Haplosporidia)-, 15 Telonema-, 15 Choanoflagellida-, and 249 Metazoa (Maxillopoda, Annelida, Lophotrochozoa, Cnidaria)-related sequences. The sequence diversity was highest in glacier samples from early April, with a Shannon diversity index $\left(\mathrm{H}^{\prime}\right)$ of 2.82 and 3.19 for $\mathrm{G}$ and $\mathrm{KG}$, respectively. Lowest diversity was found in Ocean samples from 12 May $2008\left(\mathrm{H}^{\prime}=0.59\right)$ and 30 April $2008\left(\mathrm{H}^{\prime}=1.41\right)$, which were dominated by copepod sequences.

The relative abundance of sequences identified as Dinophyceae was evenly distributed over the three locations and between different sampling days. Most Haptophyceae sequences were recovered in early spring samples from $\mathrm{O}$ and $\mathrm{G}$ samples, and then gradually decreased towards summer. Haptophyceae sequence distribution from clone libraries of the Krossfjorden Glacier samples was relatively evenly distributed over time. Sequences identified as Stramenopiles were mostly recovered from $\mathrm{G}$ and $\mathrm{KG}$ locations in earlymid-spring. Chlorophyte sequences were mostly found in clone libraries from $\mathrm{G}$ ad $\mathrm{KG}$ locations in particular on 12 May at location $\mathrm{G}$.

Among sequences related to the grazer fraction of the community, copepod-related sequences (Calanus sp. and Oithona sp.) were nearly exclusively recovered from Ocean samples from mid-spring 2008 (> 75\%). In contrast, sequences related to Ciliophora were mostly recovered from $\mathrm{G}$ and $\mathrm{KG}$ locations, in particular from $\mathrm{G}$ samples from late spring. Clones identified as Rhizaria-related sequences were mostly recovered from KG samples. Furthermore Rhizaria were overall more abundant in June samples, in particular 


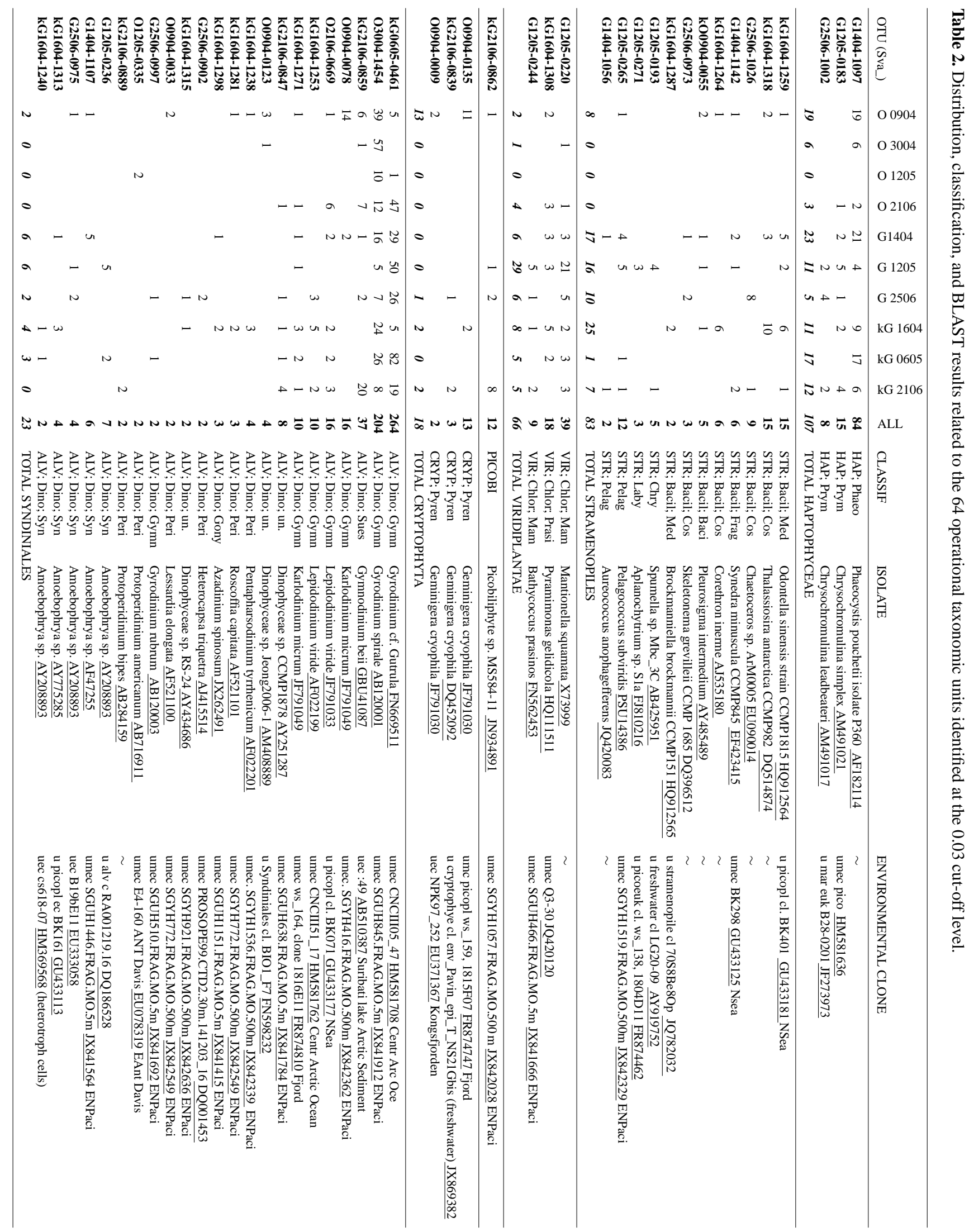




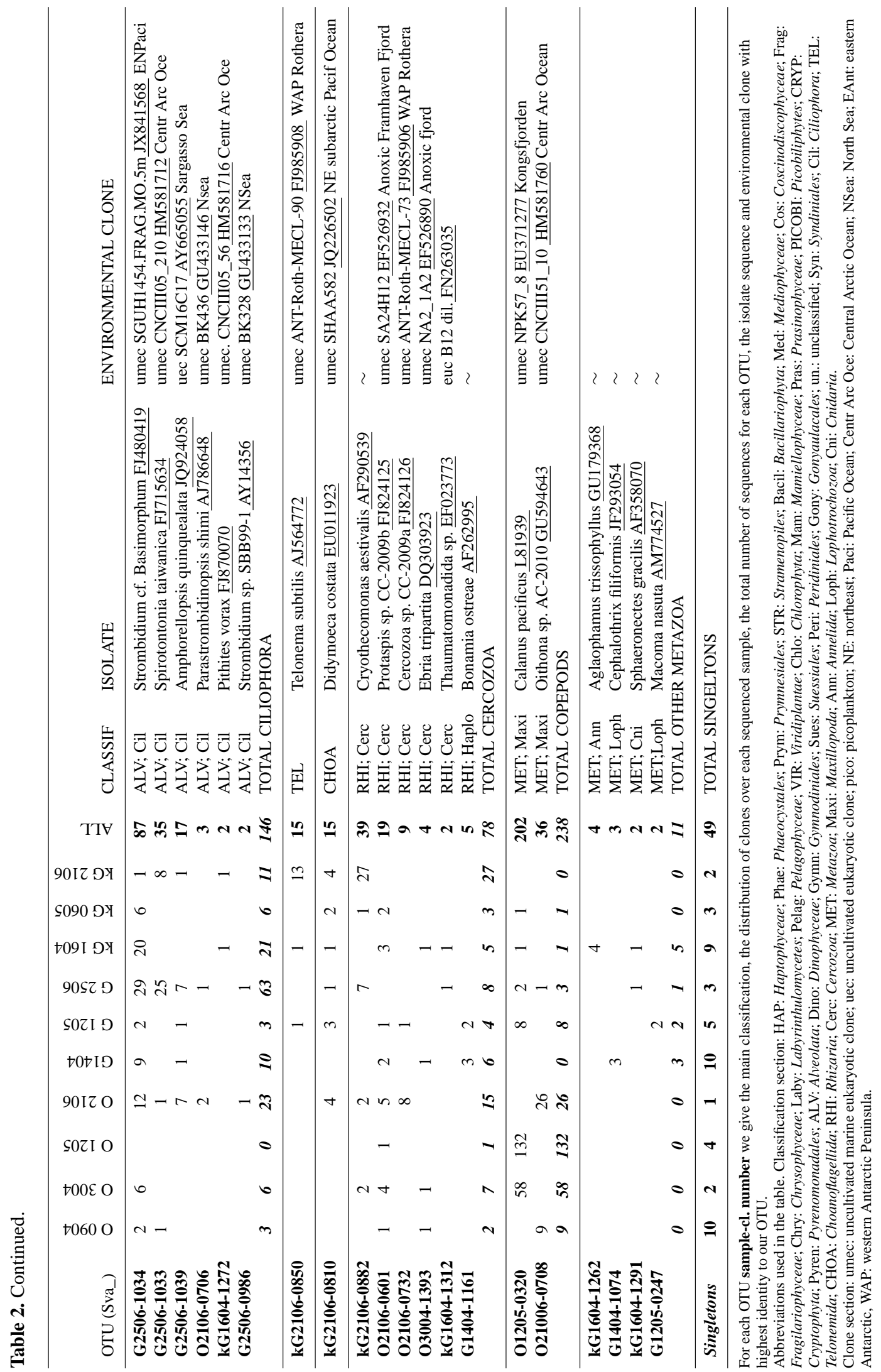


in KG and $\mathrm{O}$ samples. Choanoflagellates were mostly recovered from mid-late spring samples, and absent in most early spring samples.

\section{Discussion}

\subsection{Comparison of phytoplankton community analysis methods: pigments, microscopy and 18SrRNA gene sequencing}

In the present study we show that the combination of pigment and molecular fingerprinting, supported with occasional microscopy inspections to assess phytoplankton community structure, are highly complementary. CHEMTAX analysis of taxon-specific pigments revealed semi-quantitative differences in phytoplankton community structure at the class level over time and space. Incidental microscopy confirmed the quantitative data generated by the CHEMTAX analysis. For example, the high relative contribution of cryptophytes to total phytoplankton biomass, as revealed by CHEMTAX was confirmed by the high numbers of cryptophyte cells as visually observed for the glacier and late spring samples. Overall, the stations in close proximity to both glaciers, predominantly hosted a small cell community including cryptophytes, cyanophytes, chlorophyll $b$ containing algae, and some pennate diatoms and small ciliates. The relatively high abundances of haptophyte and diatom specific pigments in early spring samples from the Ocean station were indeed confirmed by microscopy: samples were mainly composed of Phaeocystis sp. colonies and diatoms belonging to the genera Thalassiosira, Fragilariopsis and Chaetoceros. Furthermore, specific pigment signatures suggested a high relative contribution of cyanophytes in some samples constituting up to $25 \%$ of the total phytoplankton community. Confirmation of this finding was attempted by using specific cyanobacterial primers Cya27F1 and Cya809R (Jungblut et al., 2005; Jungblut et al., 2010; Lionard et al., 2012) on DNA extracts of the $0.2-2 \mu \mathrm{m}$ size fraction. The amplification did not yield any specific cyanobacterial amplicons preventing the identification of cyanobacterial species present in the KongsfjordenKrossfjorden system. Further investigation is therefore required to assess specific cyanobacterial presence and identity in both fjords.

Species composition inferred from partial 18S rRNA gene sequencing revealed a different community composition, as compared with CHEMTAX and microscopy. Most striking was a bias towards identification of Alveolate-related sequences. Over half (760) of our 1454 environmental sequences were identified as Alveolata, among which 591 were most related to the Dinophyceae. Alveolates are known to often dominate in 18S rRNA gene libraries (Massana and Pedros-Alió, 2008). Clone libraries of the 18S rRNA gene are mostly biased towards high $18 \mathrm{~S}$ rRNA gene copy number species (Zhu et al., 2005). Other Arctic studies on marine protistan communities also observed a large dominance of Alveolata-related sequences (Lovejoy et al., 2006; Terrado et al., 2011). Analysis of protistan rRNA gene clone libraries from the Amundsen Gulf (Canadian Arctic) showed that rRNA gene clone libraries mostly consisted of OTUs identified as Ciliophora, Dinophyceae, Marine Alveolata, which are all members of the Alveolate superphyla, and furthermore Marine Stramenopile (MAST) and Prasinophyte OTUs.

In addition to the high contribution of Alveolate-related sequences, a striking difference with the CHEMTAX approach was the underrepresentation of diatom (Stramenopile) and the near absence of cryptophyte sequences. This underlines that when solely applying molecular methods, the phytoplankton community is not realistically reflected by analysis of the 18S rRNA gene. On the other hand analysis of the $18 \mathrm{~S}$ rRNA gene also has an important added value since it provides information on non-pigmented species and on the identity of taxonomically unidentifiable smaller species belonging to relevant marine taxonomic groups such as chlorophytes, prasinophytes, Picozoa, haptophytes, chrysophytes and pelagophytes, as demonstrated for the two Arctic fjords under study (Table 2). Moreover, 18S rRNA gene sequencing provided qualitative information on smaller heterotrophs belonging to the Ciliophora, Syndiniales, Choanoflagellates, Cercozoa, and Telonema. High throughput sequence analysis of RNA instead of the 18S rRNA gene might provide a more accurate reflection of the active/live part of the plankton community. In addition, it has been proposed that RNA based libraries are more representative of environmental conditions prevailing at the time of sampling (Stoeck et al., 2007). For future protistan and phytoplankton community studies we recommend the sequencing of rRNA and RNA libraries through next generation sequencing methodologies and complementary taxon-specific pigment analysis.

\subsection{Kongsfjorden springtime phytoplankton dynamics}

Typically, Kongsfjorden spring blooms peak in May and consist of Phaeocystis pouchetii and diatoms (Thalassiosira spp., Chaetoceros spp. and Fragilariopsis spp.) (Seuthe et al., 2011; Hodal et al., 2012; Hegseth and Tverberg, 2013). However, in recent years, the bloom timing varied from April to the end of May. (Hegseth and Tverberg, 2013). Shifts in bloom timing have been attributed to the variable presences of sea ice and anomalous wintertime AW inflow events into the fjord. The mooring site within Kongsfjorden revealed important wintertime AW inflow events in three consecutive years (2006-2008). (Hegseth and Tverberg, 2013). In our sampling years of 2007 and 2008 the winter cooling of the fjord was interrupted by several AW incursions in surface waters. Hegseth and Tverberg (2013) reported decreased spring bloom Chl $a$ values and altered taxonomic composition during the bloom period. The composition shift was most pronounced during the 2007 spring bloom with a Phaeocystis-pouchetii-dominated community 
(>90\%) complemented by small flagellates and only a minor contribution of diatoms $(1 \%)$. The bloom was delayed to mid-May and strongly reduced in duration. By 23 May only $10 \%$ of the bloom remained, and the succession towards a flagellate community had started. These data enabled us to situate our 2007 late spring sampling period (22 May to 25 June) within the post-bloom period. Kongsfjorden phytoplankton succession has been reported to shift to a nano- and picoplankton- and dinoflagellatedominated community during summer (Keck et al., 1999; Rokkan Iversen and Seuthe, 2011; Seuthe et al., 2011). Our 2007 data showed that haptophyte and diatom pigments, which normally constitute the largest fraction of the spring community (Fig. 5), had mostly disappeared although fragments of senescent Phaeocystis colonies were still observed at the $\mathrm{O}$ and $\mathrm{M}$ stations. Moreover, the late spring 2007 nutrient data showed largely nutrient-depleted surface waters. Despite the relatively diatom-poor 2007 bloom reported by Hegseth and Tverberg (2013), our late spring nutrient data also showed silica concentrations below $2 \mu \mathrm{M}$, suggesting that diatoms might have peaked earlier than the Phaeocystis sp. bloom, in- or outside Kongsfjorden. The observed succession from haptophytes and diatoms to the nanoand picophytoplankton-sized classes (chlorophytes, cryptophytes, dinoflagellates and cyanophyte) is in agreement with other studies conducted in Kongsfjorden during late spring and summer (Keck et al., 1999; Rokkan Iversen and Seuthe, 2011; Seuthe et al., 2011).

In 2008, Hegseth and Tverberg (2013) measured an increase in Chl $a$ (up to $1.6-1.9 \mu \mathrm{g} \mathrm{L}^{-1}$ ) between 18 and 21 April (JD 109 to 112) at the central Kongsfjorden monitoring site. They speculated that this was the initiation of the spring bloom, composed of Phaeocystis sp. (90\%) and diatoms (7\%), (Fragilariopsis sp., Thalassiosira spp., Chaetoceros sp. and pennate diatoms). Our early April CHEMTAX and microscopy data showed similar taxonomic composition and maximal Chl $a$ values at the Ocean station of $1.7 \mu \mathrm{g} \mathrm{L}^{-1}$ on 16 April (JD 107). From mid-April 2008 onwards the spring bloom did not develop steadily at all fjord locations. Chl $a$ values in Kongsfjorden Middle station showed a small increase around 19 April to 0.7 and $1 \mu \mathrm{g} \mathrm{L}^{-1}$ in surface waters and $20 \mathrm{~m}$ samples, respectively, whereas Chl $a$ levels from all other stations stayed below $0.5 \mu \mathrm{g} \mathrm{L}^{-1}$. Between 19 and 26 April we measured a sharp decrease in Chl $a$ at the Ocean and Middle station, dropping down to $<0.5 \mu \mathrm{g} \mathrm{L}-1$. This coincided with a high wind velocity period of 4 days (daily average wind speeds 6.95 and $8.2 \mathrm{~m} \mathrm{~s}^{-1}$ ) from the NWW direction, which freely blew into Kongsfjorden, which has a northwest-southeast orientation. The high winds combined with low air temperatures (wind chill $-37^{\circ} \mathrm{C}$ ) likely caused vertical mixing and cooling of the water column. This was confirmed by the CTD profiles (Fig. 2) showing a homogeneous water column for the upper $60 \mathrm{~m}$ at the $\mathrm{O}$ and $\mathrm{M}$ stations. The resultant vertical redistribution of phytoplankton biomass may have interrupted bloom formation, and could cause changes in phytoplankton composition, as found before (Piquet et al., 2011; Hegseth and Tverberg, 2013). After the wind event, a period characterized by relatively calm southerly winds permitted stabilization of the water column and therefore biomass buildup. Chl $a$ values eventually increased after 28 April up to our last sampling day on 12 May, reaching up to 2.5 and $2.8 \mu \mathrm{g} \mathrm{L}^{-1}$ at the Ocean station at 0 and $20 \mathrm{~m}$, respectively, and 2 and $2.5 \mu \mathrm{g} \mathrm{L}^{-1}$ at 0 and $20 \mathrm{~m}$ depth, respectively, on 2 May at Kongsfjorden Middle station. Maximal Chl $a$ values from our data were still well below maximal $\mathrm{Chl} a$ springtime values, which can reach up to $\sim 13 \mu \mathrm{g} \mathrm{L}^{-1}$ as recorded in other years (Hop et al., 2002; Hegseth and Tverberg, 2013). This indicates that the 2008 spring bloom was disrupted and characterized by low biomass throughout.

\subsection{Cyanobacteria as potential marker species}

Our pigment data are the first showing the relative importance of cyanophytes in the Kongsfjorden-Krossfjorden system. Cyanobacteria are ubiquitous and important contributors to primary production in warmer marine waters, and are typically considered to be absent from high-latitude polar marine waters (Partensky et al., 1999). Just recently a few studies have observed cyanobacteria in Arctic waters. Cottrell and Kirchman (2009) found Synechococcus spp. in samples from the Chukchi and Beaufort Sea, while Díez et al. (2012) reported the presence of cyanobacterial nifH genes in samples collected in the Fram Strait, west from Spitsbergen. We propose that the regular Atlantic water incursions might have contributed to transport of cyanobacterial species from the milder Atlantic currents into Kongsfjorden. A temperate origin for the Chukchi and Beaufort Sea Synechococcus spp. was also proposed by Cottrell and Kirchman (2009). In the past, Atlantic water inflow events have been associated with observations of the haptophyte Emiliania huxleyi in Svalbard and Arctic waters (Hasle and Heimdal, 1998; Hop et al., 2002; Hegseth and Sundfjord, 2008). As a result, this species was proposed as a marker species for AW intrusion in the area. However in our 2007 and 2008 samples, two years with strong AW influence, no E. huxleyi cells were found. Instead, cyanobacterial presence might be a more promising AW marker as suggested earlier (Gradinger and Lenz, 1989).

\subsection{Potential freshwater species intrusions}

Alternatively, in polar freshwater systems, such as lakes, melt water ponds and streams, cyanophytes are major contributors to primary production (Jungblut et al., 2010; Harding et al., 2011; Vincent and Quesada, 2012). As meltwater was affecting the Kongsfjorden-Krossfjorden system throughout our sampling period, one could speculate that cyanophyte pigments could have originated from freshwater sources. If the cyanophyte pigments originated from the freshwater runoff or processes related to glacial melting, one would expect 
clear differences in cyanophyte pigment abundance between the different layers as the high buoyancy of small freshwater cyanophytes would confine them within the surface melt water layer of the fjord. However, our analysis indicated that overall cyanophyte pigment abundance at $20 \mathrm{~m}$ depth was similar to the abundance at the surface, providing no evidence for a freshwater-related population. Cyanophyte pigment abundances were overall higher in late spring than early spring, when freshwater input was highest. This could provide circumstantial evidence for a freshwater origin. However, we did not find higher cyanophyte pigment abundances at the glacier station, which was most influenced by meltwater input in late spring, weakening the likelihood for a freshwater origin. Overall our data do not provide conclusive evidence for a freshwater origin.

Our samples also revealed relatively important chlorophyte pigment abundances. A potential non-marine origin of the chlorophytes was examined by comparing depth and spatially related differences in pigment abundance. Chlorophyte pigments were slightly more abundant in surface water samples than in $20 \mathrm{~m}$-depth samples, in particular at inner fjord locations, while highest chlorophyte pigment abundances were found at the Ocean station, suggesting the presence of marine chlorophytes. Therefore our findings mean either that chlorophytes have a slight physiological advantage in surface waters (more light, less salinity) or that marine as well as freshwater chlorophytes were present in the study area. The latter is a plausible explanation, as the chlorophyte group was inferred from $\mathrm{Chl} b$ : a pigment present in chlorophytes and prasinophytes. HPLC does not enable the distinction between both classes, and thus the relative pigment distribution of chlorophytes might very well have consisted of freshwater chlorophytes at the inner locations and in surface waters, while at the Ocean station marine prasinophytes may have been relatively more abundant. In both cases, identification of cyanophytes and chlorophytes in polar marine systems influenced by meltwater incursions requires further investigation in order to determine their origin: marine or from freshwater sources.

\subsection{Influence of environmental conditions on springtime phytoplankton biomass and composition}

Differences in both phytoplankton biomass ( $\mathrm{Chl} a$ ) and composition between stations Ocean and Kongsfjorden Middle versus Krossfjorden Middle and both glacier stations were striking. The inner locations had significantly lower Chl $a$ values, and showed a higher relative abundance of nanopicoplankton groups throughout the early spring sampling period. At the Ocean site, $2008 \mathrm{Chl} a$ values and diatom pigments were positively correlated (ln transformed Chl $a ; y=$ $32.407 x+56.815, R^{2}=0.736$ ). Other locations showed relatively low diatom pigment concentrations. Diatoms are considered primary biomass contributors in polar waters (Varela et al., 2002), and their relatively lower contribution at Kongs- fjorden Glacier and Krossfjorden stations probably was an important determinant for lower Chl $a$ values. In support of this, Rokkan Iversen and Seuthe (2011) showed a low contribution of $<10 \mu \mathrm{m}$-sized cells (expressed as \% Chl $a$ ) during the spring bloom at their monitoring location in central Kongsfjorden, while comprising the largest fraction of the phytoplankton (75-95\%) during the rest of the year.

The Kongsfjorden and Krossfjorden Glacier locations showed lower water temperatures with subzero values. We speculate that the prevailing lower water temperatures prevented the development of a spring bloom at those locations. On the other hand, the nutrient data demonstrated uptake and hence phytoplankton growth at these locations although the observed lower silica uptake rates indicated decreased quantitative importance of diatoms. The Kongsfjorden Glacier data showed a highest $\mathrm{Chl} a$ value of $0.8 \mu \mathrm{g} \mathrm{L}-1$ on 5 May, corresponding with an intrusion event of saltier and warmer water (Fig. 2, JD 124) and thus probably reflecting transport of phytoplankton from the Middle station.

In addition to the relatively colder conditions, inner fjord locations were also characterized by lower salinities. The surface waters at the Krossfjorden Glacier station were significantly fresher due to sea ice melting leading to surface stratification (Fig. 2) during early spring (2008 campaign). Salinities near the Kongsfjorden Glacier also showed slightly reduced values during the 2008 campaign. Sea ice was largely absent from Kongsfjorden, and reduced salinities were probably caused by early springtime glacier melting. The overall significantly higher Kd values measured near the glacier support an early onset of glacier meltwater, enriched in sediment particles, during early spring. Several other polar studies have reported shifts in phytoplankton communities towards smaller-sized phytoplankton species, as a result of meltwater input. Along the western Antarctic Peninsula reduced water salinities were correlated with increased cryptophytes abundance (Moline et al., 2004), whereas diatom and prymnesiophytes were associated with saltier water masses. The relatively higher proportion of nano-picoplankton at the inner fjord locations during springtime could have been partially mediated by glacier influence expressed in lower salinities and temperatures. Also, it cannot be ruled out that meltwater induced surface stabilization that caused rapid sinking of diatoms out of the euphotic zone, the latter becoming highly shallow towards the end of spring. In addition, the suboptimal irradiance conditions resulting from strong light attenuation near the glaciers could also have limited phytoplankton growth. Our molecular fingerprinting data further support the hypothesis that early glacier influence was at hand, as spring phytoplankton community fingerprints from inner fjord stations shared more similarity to late spring communities than the outer fjord spring community. The transect data from Hegseth and Tverberg (2013) from spring 2006 show an early spring bloom with high Chl $a$ concentrations $\left(13 \mu \mathrm{g} \mathrm{L}^{-1}\right)$ measured in Kongsfjorden in particular at stations $\mathrm{Kb} 0-\mathrm{Kb} 2$ corresponding to our Ocean and Middle 
station, whereas the inner Kongsfjorden (Kb5) corresponding to our Glacier station had much lower Chl $a$ concentrations $\left(<5 \mu \mathrm{g} \mathrm{L}{ }^{-1}\right)$. In other words, even during a high phytoplankton biomass season, glacier proximity appears to limit biomass.

\section{Conclusions}

In the present study we generated a data set enabling a comparison in phytoplankton springtime dynamics and composition between the two adjacent fjords. Our results show that, despite their shared Ocean connection and their apparent proximity, springtime phytoplankton dynamics differ significantly between the fjords, as was proposed before for summertime communities (Piquet et al., 2010). Our springtime mini-transect survey show that Kongs- and Krossfjorden springtime phytoplankton conditions are strongly governed by oceanic as well as glacier influence. Both are fed by numerous glaciers, but the sediment discharge is more important in the inner Kongsfjorden. Furthermore, Kongsfjorden appeared to be more influenced by AW inflow, mediating higher water temperatures, whereas Krossfjorden stayed much colder throughout early spring, and shared much resemblance to the inner Kongsfjorden conditions. These physical differences appeared to affect the development of phytoplankton biomass. Near-glacier-vicinity conditions influenced phytoplankton community composition as early as spring, with a limited biomass buildup and a relatively smaller sized phytoplankton community, resembling late spring communities sampled within glacier meltwater plumes. Our microscopy and sequence analysis suggests that the grazer community composition is also affected. Copepods were dominating in outer station locations, where diatoms and Phaeocystis sp. dominated, whereas ciliates were the dominant grazer fraction at inner fjord locations. From this we can speculate that an earlier onset of glacier melting in spring will limit biomass buildup and facilitate a smallersized phytoplankton community, mostly grazed by ciliates which may channel organic carbon towards the microbial loop, rather than to higher trophic levels. We therefore conclude that ongoing climate change, leading to more Atlantic water intrusions in Kongsfjorden and an early glacier meltwater onset, will affect phytoplankton biomass composition and thus may have a cascading effect on the fate of organic carbon and, hence, on biogeochemical carbon cycling.
Acknowledgements. This research was financed by NWO, as part of the IPY-PAME framework. Field work at Koldeway station was supported and financed by AWI. We thank the Kings Bay AS personnel, in particular the captain of MS Teisten and the Kings Bay Marine Laboratory manager, for their excellent logistic support. Thanks to Douwe Maat for his valuable contribution during the 2008 fieldwork campaign. Nutrient analyses were run at the NIOZ by Jan van Ooijen. We are grateful for the microscopy analyses performed by Loes A. H. Venekamp.

Edited by: K. Suzuki

\section{References}

Buchholz, F., Buchholz, C., and Weslawski, J. M.: Ten years after: krill as indicator of changes in the macro-zooplankton communities of two Arctic fjords, Polar Biol., 33, 101-113, 2010.

Cottier, F., Tverberg, V., Inall, M., Svendsen, H., Nilsen, F., and Griffiths, C.: Water mass modification in an Arctic fjord through cross-shelf exchange: the seasonal hydrography of Kongsfjorden, Svalbard, J. Geophys. Res. C, 110, 1-18, 2005.

Cottrell, M. T. and Kirchman, D. L.: Photoheterotrophic microbes in the Arctic Ocean in summer and winter, Appl. Environ. Microbiol., 75, 4958-4966, 2009.

Coupel, P., Jin, H. Y., Joo, M., Horner, R., Bouvet, H. A., Sicre, M., Gascard, J., Chen, J. F., Garcon, V. and Ruiz-Pino, D.: Phytoplankton distribution in unusually low sea ice cover over the Pacific Arctic, Biogeosciences, 9, 4835-4850, doi:10.5194/bg9-4835-2012, 2012.

Díez, B., Pedros-Alió, C., Marsh, T., and Massana, R.: Application of denaturing gradient gel electrophoresis (DGGE) to study the diversity of marine picoeukaryotic assemblages and comparison of DGGE with other molecular techniques, Appl. Environ. Microbiol., 67, 2942-2951, 2001.

Díez, B., Bergman, B., Pedros-Alió, C., Anto, M., and Snoeijs, P.: High cyanobacterial nifH gene diversity in Arctic seawater and sea ice brine, Environ. Microbiol. Rep., 4, 360-366, 2012.

Gradinger, R. and Lenz, J.: Picocyanobacteria in the High Arctic, Mar. Ecol. Prog. Ser., 52, 99-101, 1989.

Hammer, O., Harper, D. A. T., and Ryan, P. D.: PAST: Paleontological statistics software package for education and data analysis, Palaeont. Electr., 4, 38-47, 2001.

Harding, T., Jungblut, A. D., Lovejoy, C., and Vincent, W. F.: Microbes in High Arctic Snow and Implications for the Cold Biosphere, Appl. Environ. Microbiol., 77, 3234-3243, 2011.

Hartl, D. L., Moriyama, E. N., and Sawyer, S. A.: Selection intensity for codon bias, Genetics, 138, 227-234, 1994.

Hasle, G. R. and Heimdal, B. R.: The net phytoplankton in Kongsfjorden, Svalbard, July 1988, with general remarks on species composition of arctic phytoplankton, Polar Res., 17, 31-52, 1998.

Hegseth, E. N. and Sundfjord, A.: Intrusion and blooming of Atlantic phytoplankton species in the high Arctic, J. Mar. Syst., 74, 108-119, 2008.

Hegseth, E. N. and Tverberg, V.: Effect of Atlantic water inflow on timing of the phytoplankton spring bloom in a high Arctic fjord (Kongsfjorden, Svalbard), J. Mar. Syst., 113-114, 94-105, 2013. 
Heuer, H., Wieland, J., Schönfeld, J., Schönwäalder, A., Gomes, N. C. M., and Smalla, K.: Bacterial community profiling using DGGE and TGGE analysis, in: Environmental molecular microbiology: protocols and applications., Rouchelle, P. (Ed.), Horizon Scientific Press, Hymondham, United Kingdom, 177-190, 2001.

Hodal, H., Falk-Peterson, S., Hop, H., Kristiansen, S., and Reigstad, M.: Spring bloom dynamics in Kongsfjorde, Svalbard: nutrients, phytoplankton, protozoans and primary production, Pol. Biol., 35, 191-203, 2012.

Hop, H., Falk-Peterson, S., Svendsen, H., Kwasniewski, S., Pavlov, V., Pavlova, O., and Soride, J. E.: Physical and biological characteristics of the pelagic system across Fram Strait to Kongsfjorden, Prog. Oceanogr., 71, 182-231, 2006.

Hop, H., Pearson, T., Hegseth, E. N., Kovacs, K. M., Wiencke, C., and Kwasniewski, S.: The marine ecosystem of Kongsfjorden, in Svalbard, Polar Res., 21, 167-208, 2002.

Jungblut, A., Hawes, I., Mountfort, D., Hitzfeld, B., Dietrich, D., Burns, B., and Neilan, B.: Diversity within cyanobacterial mat communities in variable salinity meltwater ponds of McMurdo Ice Shelf, Antarctica, Environ. Microbiol., 7, 519-529, 2005.

Jungblut, A. D., Lovejoy, C., and Vincent, W. F.: Global distribution of cyanobacterial ecotypes in the cold biosphere, ISME J., 4, 191-202, 2010.

Keck, A., Wiktor, J., Hapter, R., and Nilsen, R.: Phytoplankton assemblages related to physical gradients in an arctic, glacier-fed fjord in summer, ICES J. Mar. Sci., 56, 203-214, 1999.

Li, W. K. W., McLaughlin, F. A., Lovejoy, C., and Carmack, E. C.: Smallest algae thrive as the Arctic Ocean freshens, Science, 326, 539-539, 2009.

Lionard, M., Pequin, B., Lovejoy, C., and Vincent, W. F.: Benthic cyanobacterial mats in the high arctic: multi-layer structure and fluorescence responses to osmotic stress, Frontiers in Microbiol., 3, 140, 2012.

Lovejoy, C., Massana, R., and Pedrós-Alió C.: Diversity and distribution of marine microbial eukaryotes in the Arctic Ocean and adjacent seas, Appl. Environ. Microbiol., 72, 3085-3095, 2006.

Mackey, M. D., Mackey, D. J., Higgins, H. W., and Wright, S. W.: CHEMTAX - a program for estimating class abundances from chemical markers: application to HPLC measurements of phytoplankton, Mar. Ecol. Prog. Ser., 144, 265-283, 1996.

Massana, R. and Pedros-Alió, C.: Unveiling new microbial eukaryotes in the surface ocean, Curr. Opin. Microbiol., 11, 213-218, 2008.

Moline, M., Claustre, H., Frazer, T., Schofield, O., and Vernet, M.: Alteration of the food web along the Antarctic Peninsula in response to a regional warming trend, Global Change Biol., 10, 1973-1980, 2004.

Montes-Hugo, M., Doney, S. C., Ducklow, H. W., Fraser, W., Martinson, D. G., Stammerjohn, S. E., and Schofield, O.: Recent changes in phytoplankton communities associated with rapid regional climate change along the Western Antarctic Peninsula, Science, 323, 1470, 2009.

Muyzer, G., de Waal, E. C., and Uitterlinden, A. G.: Profiling of complex microbial populations by denaturing gradient gel electrophoresis analysis of polymerase chain reaction-amplified genes coding for 16S rDNA, Appl. Environ. Microbiol., 59, 695$700,1993$.
Not, F., Valentin, K., Romari, K., Lovejoy, C., Massana, R., Töbe, K., Vaulot, D., and Medlin, L. K.: Picobiliphytes: a marine picoplanktonic algal group with unknown affinities to other eukaryotes, Science, 315, 352-355, 2007.

Partensky, F., Blanchot, J. and Vaulot, D.: Differential distribution and ecology of Prochlorococcus and Synechococcus in oceanic waters: a review, in: Marine Cyanobacteria, Charpy, L. and Larkum, A. W. D. (Eds.), Institute of Oceanography, Monaco, 457-475, 1999.

Piquet, A. M. -T., Scheepens, J. F., Bolhuis, H., Wiencke, C., and Buma, A. G. J.: Variability of protistan and bacterial communities in two Arctic fjords (Spitsbergen), Polar Biol., 33, 15211536, 2010.

Piquet, A. M.-T., Bolhuis, H., Meredith, M. P., and Buma, A. G. J.: Shifts in coastal Antarctic marine microbial communities during and after melt water-related surface stratification, FEMS Microbiol. Ecol., 76, 413-427, 2011.

Rokkan Iversen, K. and Seuthe, L.: Seasonal microbial processes in a high-latitude fjord (Kongsfjorden, Svalbard): I. Heterotrophic bacteria, picoplankton and nanoflagellates, Polar Biol., 34, 731749, 2011.

Schlichtholz, P. and Goszczko, I.: Interannual variability of the Atlantic water layer in the West Spitsbergen Current at $76.5^{\circ} \mathrm{N}$ in summer 1991-2003, Deep-Sea Res. Part I, 53, 608-626, 2006.

Schloss, P. D., Westcott, S. L., Ryabin, T., Hall, J. R., Hartmann, M., Hollister, E. B., Lesniewski, R. A., Oakley, B. B., Parks, D. H., Robinson, C. J., Sahl, J. W., Stres, B., Thallinger, G. G., Van Horn, D. J., and Weber, C. F.: Introducing mothur: Open-Source, Platform-Independent, Community-Supported Software for Describing and Comparing Microbial Communities, Appl. Environ. Microbiol., 75, 7537-7541, 2009.

Seenivasan, R., Sausen, N., Medlin, L. K.. and Melkonian, M.: Picomonas judraskeda gen. et sp. nov.: the first identified member of the Picozoa phylum nov., a widespread group of picoeukaryotes, formerly known as "picobiliphytes", PloS one, 8, e59565, doi:10.1371/journal.pone.0059565, 2013.

Seuthe, L., Rokkan Iversen, K., and Narcy, F.: Microbial processes in a high latitude fjord (Kongsfjorden, Svalbard): II Ciliates and dinoflagellates, Polar Biol., 34, 751-766, 2011.

Stoeck, T., Zuendorf, A., Breiner, H., and Behnke, A.: A molecular approach to identify active microbes in environmental eukaryote clone libraries, Microb. Ecol., 53, 328-339, 2007.

Svendsen, H., Beszczynska-Møller, A., Hagen, J. O., Lefauconnier, B., Tverberg, V., Gerland, S., Ørebæk, J. B., Bischof, K., Papucci, C., Zajaczkowski, M., Azzolini, R., Bruland, O., Wiencke, C., Winther, J., and Dallman, W.: The physical environment of the Kongsfjorden-Krossfjorden, an arctic fjord system in Svalbard, Polar Res., 21, 133-166, 2002.

Tamura, K., Dudley, J., Nei, M., and Kumar, S.: MEGA4: Molecular Evolutionary Genetics Analysis (MEGA) software version 4.0, Mol. Biol. Evol., 24, 1596-1599, 2007.

Terrado, R., Medrinal, E., Dasilva, C., Thaler, M., Vincent, W. F., and Lovejoy, C.: Protist community composition during spring in an Arctic flaw lead polynya, Polar Biol., 34, 1901, 2011.

Van Leeuwe, M. A., Villerius, L. A., Roggeveld, J., Visser, R. J. W., and Stefels, J.: An optimized method for automated analysis of algal pigments by HPLC, Mar. Chem., 102, 267-275, 2006.

Varela, M., Fernandez, E., and Serret, P.: Size-fractionated phytoplankton biomass and primary production in the Gerlache and 
south Bransfield Straits (Antarctic Peninsula) in Austral summer 1995-1996, Deep-Sea Res. Pt II, 49, 749-768, 2002.

Vincent, W. F. and Quesada, A.: Cyanobacteria in high latitude lakes, rivers and seas, in: Ecology of Cyanobacteria II: Their Diversity in Space and Time, Springer, New York (USA), 371-385, 2012.
Zhu, F., Massana, R., Not, F., Marie, D., and Vaulot, D.: Mapping of picoeukaryotes in marine ecosystems with quantitative PCR of the 18S rRNA gene, FEMS Microbiol. Ecol., 52, 79-92, 2005.

Zhu, L. and Bustamante, C. D.: A composite-likelihood method for detecting directional selection from DNA sequence data, Genetics, 170, 1411-1421, 2005. 